\title{
KONTRIBUSI PAJAK DAERAH DAN RETRIBUSI DAERAH TERHADAP PENDAPATAN ASLI DAERAH ( PAD ) GUNA MENDUKUNG PELAKSANAAN OTONOMI DAERAH
}

\author{
Oleh : \\ Henny Mahmudah \\ Fakultas Ekonomi Universitas Islam Lamongan \\ E-mail/No.Hp: henny_la@yahoo.co.id
}

\begin{abstract}
Following writing will try to work through how relationship among accepting region taxes and region retribution to PAD'S step-up by use of approaching Error Correction Model( ECM) by use of annual data begins year 1990 until years 2010. It utilizes error correction's approaching with consideration that this model feels equal to word relationship among variable one is analyzed well that in the short term and also on a long term.
\end{abstract}

Keywords: Region taxes, Region retribution, $P A D$

\begin{abstract}
Abstrak
Tulisan berikut akan mencoba membahas bagaimana hubungan antara penerimaan pajak daerah dan retribusi daerah terhadap peningkatan PAD dengan menggunakan pendekatan Error Correction Model ( ECM ) dengan menggunakan data tahunan mulai tahun 1990 hingga tahun 2010. Digunakannya pendekatan error correction dengan pertimbangan bahwa model ini sanggup untuk menjelaskan hubungan antara variabel yang diteliti baik itu dalam jangka pendek maupun dalam jangka panjang.
\end{abstract}

Kata Kunci : Pajak Daerah, Retribusi daerah, PAD

\section{PENDAHULUAN}

Hakekat pembangunan daerah sebagai bagian dari pembangunan nasional adalah terwujudnya kesejahteraan umum yang berkeadilan sosial sebagaimana telah diamanatkan dalam pembukaan UUD 1945. Yang berarti bahwa dengan adanya proses pembangunan yang dilaksanakan secara terus menerus dari waktu ke waktu diharapkan adanya perubahan yang signifikan terhadap tingkat kesejahteraan masyarakat secara keseluruhan dengan berazaskan adil dan merata. Sedangkan terwujudnya kesejahteraan rakyat dapat diukur dari tingkat pendidikan, kesehatan, sosial, budaya, politik dan keamanan. Berbagai ukuran tersebut pada dasarnya berpangkal tolak pada tingkat perekonomian. Oleh karena itu untuk program pembangunan daerah lebih ditekankan pada pembangunan ekonomi.

Dengan diberlakukannya UU No.

32 Tahun 2004 tentang Pemerintahan 
Daerah dan UU No. 33 Tahun 2004 tentang Perimbangan Keuangan antara Pemerintah Pusat dan Pemerintahan Daerah memberikan kewenangan dan keleluasaan yang lebih luas bagi Pemerintah Kabupaten (Pemkab) sebagai pelaksana dan promotor pembangunan di daerah untuk mengatur dan menentukan sendiri kegiatan pembangunan wilayah yang sesuai dengan prioritas kebutuhan masyarakat setempat, tentu saja arah dan pola pembangunan daerah tetap mendukung dan mengacu pada pedoman yang telah ditetapkan.

Pelaksanaan otonomi daerah yang dititk beratkan pada daerah kabupaten dan daerah kota dimulai dengan adanya penyerahan sejumlah kewenangan ( urusan ) dari pemerintah pusat ke pemerintah daerah yang bersangkutan. Penyerahan berbagai kewenangan dalam rangka desentralisasi ini tentunya harus disertai dengan penyerahan dan pengalihan pembiayaan. Sumber pembiayaan yang paling penting adalah pembiayaan yang dikenal dengan Pendapatan Asli Daerah ( PAD ), dimana merupakan sumber penerimaan yang signifikan bagi pembiayaan rutin dan pembangunan disuatu daerah otonom. Jumlah komponen penerimaan pajak daerah dan retribusi daerah sangat dipengaruhi oleh banyaknya jenis pajak daerah dan retribusi daerah yang diterapkan dan disesuaikan dengan peraturan yang berlaku yang terkait dengan penerimaan kedua komponen tersebut. Disamping penerimaan tersebut diatas keberhasilan PAD juga dipengaruhi oleh faktor-faktor seperti kemampuan personalia di daerah dan kelembagaan pemerintah daerah.

Pengertian Pendapatan Asli Daerah ( PAD ) sumber-sumber dalam wilayahnya sendiri yang dipungut berdasarkan Peraturan Daerah sesuai dengan peraturan perundangan yang berlaku. ( Abdul Halim,2004 ). Pendapatan Asli daerah ( PAD ) merupakan salah satu komponen sumber Pendapatan Daerah sebagaimana dalam Pasal 79 Undang-Undang Nomor 22 Tahun 1999 tentang Pemerintahan Daerah ( UU 22/1999 ), bahwa Sumber Pendapatan Daerah terdiri dari Pendapatan Asli Daerah yaitu Hasil Pajak Daerah, Hasil Retribusi Daerah Hasil Perusahaan milik daerah dan hasil pengelolaan kekayaan daerah yang dipisahkan dan lain-lain pendapatan asli daerah yang sah. Dana Perimbangan, Pinjaman Daerah Lain-lain dan Pendapatan Daerah yang sah

Berdasarkan Pasal 79 UU 22/1999 tersebut dapat disimpulkan PAD adalah sesuatu yang diperoleh Pemerintah Daerah yang dapat diukur dengan uang karena kewenangan ( otoritas ) yang diberikan masyarakat dapat berupa hasil pajak Daerah dan Retribusi Daerah, hasil perusahaan milik daerah dan pengelolaan kekayaan daerah serta lain-lain pendapatan daerah yang sah. Dari beberapa komponen PAD tersebut, maka 
yang perlu mendapatkan perhatian adalah Pajak Daerah dan Retribusi Daerah, karena kedua jenis PAD ini baik secara langsung maupun tidak langsung akan membenani rakyat.

Disamping itu ketentuan Pasal 79 juga mengisyaratkan bahwa di dalam penyelenggaraan fungsi-fungsi Pemerintahan Daerah, Kepala Daerah Kabupaten/Kota diharapkan dapat mengelola dan memanfaatkan seluruh sumber pendapatan daerah yang dimilikinya secara optimal khususnya di era otonomi daerah saat ini dimana kewenangan pemerintah daerah secara luas dan nyata ada pada kepala Daerah Kabupaten/Kota. Dengan kata lain diharapkan Kepala Daerah Kabupaten/Kota didalam penyelenggaraan pemerintahan dan pelaksanaan pembangunan daerah tidak terus menerus selalu menggantungkan dana ( anggaran ) dari Pemerintah Pusat melalui pembagian Dana Perimbangan.

Menurut Jaya (1999) bahwa sumber pembiayaan pembangunan yang penting untuk diperhatikan adalah penerimaan daerah sendiri, karena sumber inilah yang merupakan wujud partisipasi langsung masyarakat suatu daerah dalam mendukung proses pembangunan berupa pembayaran pajak daerah dan retribusi daerah yang pada akhirnya akan menaikkan pendapatn daerah. Lebih lanjut, didalam administrasi keuangan daerah, PAD adalah pendapatan daerah yang diurus dan diusahakan sendiri oleh daerah yang dimaksud sebagai sumber PAD guna pembangunan. Berdasarkan ketentuan dan definisi tersebut diatas, maka PAD dapat disimpulkan sebagai berikut .PAD merupakan sumber pendapatan daerah dengan mengelola dan memanfaatkan potensi daerahnya.Didalam mengelola, mengelola dan memanfaatkan potensi daerah, PAD dapat berupa pemungutan pajak, retribusi dan lain-lain pendapatan daerah yang sah.

Pengertian pajak menurut Soemitro seperti dikutip oleh Suandy, yaitu : "Pajak adalah iuran kepada kas negara berdasarkan Undang-undang ( yang dapat dipaksakan ) dengan tidak mendapat jasa imbal ( kontraprestasi ) yang langsung dapat ditunjukkan dan yang diginakan untuk membayar pengeluaran umum ( Suandy 2002;10 ). Sedangkan pengertian pajak menurut Andriani seperti yang dikutip oleh Brotodiharjo , yaitu : “ Pajak adalah iuran kepada negara ( yang dapat dipaksakan ) yang terhutang oleh yang wajib membayarnya menurut peratutran-peraturan dengan tidak mendapat prestasi kembali yang langsung dapat ditunjukkan dan yang gunanya adalah untuk membiayai pengeluaranpengeluaran umum berhubungan dengan tugas negara untuk menyelenggarakan pemerintahan “. Dari kedua difinisi tersebut diatas dapat disimpulkan bahwa pajak adalah iuran kepada kas negara yang mewajibkan seseorang untuk memenuhi syarat-syarat yang ditentukan oleh undang-undang yang dapat dipaksakan 
tanpa mendapatkan imbalan yang secara langsung dapat ditujukan dan yang gunanya untuk membiayai pengeluaranpengeluaran umum yang berhubungan dengan tugas negara untuk penyelenggaraan pemerintahan. Berdasarkan lembaga yang dapat memungut pajak, maka pajak terdiri dari :

Pajak Pusat atau Pajak Negara yaitu pajak wewenang pemungutannya ada pada Pemerintah Pusat yang pelaksanaannya dilakukan oleh

Departemen Keuangan melalui Direktorat Jenderal Pajak, contoh : Pajak Penghasilan, Pajak Penambahan Nilai, Pajak Bumi dan Bangunan, Bea Materai, Bea Perolehan Hak Atas Tanah dan BanguananPajak daerah yaitu pajak yang dipungut oleh Pemerintah Daerah (Pemerintah propinsi maupun Pemerintah Kabupaten/Kota) yang digunakan untuk m .embiayai pengeluaran penyelenggaraan pemerintahan dan pelaksanaan pembangunan daerah, contoh : Pajak Propinsi : Pajak Kendaraan Bermotor (PKB), Bea Balik Nama Kendaraan bermotor (BBNKB), dan kendaraan diatas air, Pajak Bahan Bakar Kendaraan Bermotor (PBBKB), pajak pengambilan dan pemanfaatan air bawah tanah dan air permukaan. Contoh Pajak daerah : pajak hotel, pajak restoran, pajak hiburan, pajak reklame, pajak penerangan jalan, pajak pengambilan galian golongan $\mathrm{c}$ dan pajak parkir.

Berdasarkan Undang-undang Nomor 34 Tahun 2000 Tentang perubahan atas Undang-undang Nomor 18 Tahun 1997 Tentang Pajak Daerah dan Retribusi Daerah ( UU 34/2000) Pasal 1 angka 6 dapat dijelaskan sebagai berikut :" Pajak Daerah yang selanjutnya disebut Pajak adalah iuran wajib yang dilakukan oleh orang pribadi atau badan kepada daerah tanpa imbalan langsung yang seimbang yang dipaksakan berdasarkan peraturan perundang-undangan yang berlaku yang digunakan untuk membiayai penyelenggaraan pemerintahan daerah dan pembangunan daerah. Pajak Daerah harus ditetapkan dengan Peraturan Daerah setelah mendapatkan persetujuan DPRD dan tidak boleh bertentangan dengan Pajak Pemerintah Pusat serta tidak boleh bertentangan dengan kebijakan pemerintah.

Menurut Sproule-Jones dan White (1998) bahwa Retribusi (user fees) adalah semua biaya yang dikenakan pada semua individu untuk penggunaan layanan yang memberikan manfaat langsung kepada mereka. Retribusi daerah yang juga termasuk komponen PAD merupakan penerimaan yang diterima oleh Pemerintah Daerah setelah memberikan pelayanan tertentu kepada penduduk yang mendiami wilayah yuridisnya. Perbedaan yang tegas antara pajak daerah dan retribusi daerah terletak kontraprestasi yang diberikan oleh pemerintah daerah.

Baik pajak daerah maupun retribusi daerah keduanya diatur dalam peraturan yang dikeluarkan oleh Pemerintah Daerah dan disetujui oleh 
Lembaga Perwakilan Rakyat serta dipungut oleh lembaga yang berada di dalam struktur pemerintah daerah yang bersangkutan.

Masing-masing tingkatan daerah memiliki lapangan retribusi daerah yang berbeda-beda. Lapangan retribusi daerah Propinsi antara lain adalah Retribusi Bahan Golongan C, Uang Leges, Retribusi Pemeriksaan Kendaraan Bermotor, dan Retribusi Pemakain Tanah Pemerintah Daerah. Sedangkan lapangan retribusi Kabupaten/Kota antara lain adalah Leges, Retribusi Terminal, Retribusi Pasar, Retribusi Reklame dan Retribusi Pelelangan Ikan.

Penelitian ini dilakukan di Kabupaten Lamongan dengan mengambil data pada tahun 1990 - 2010. Untuk penyususnan penelitian ini, penulis melakukan penelitian yang bersifat diskriptif, yaitu berusaha menggambarkan dan menafsirkan data mengenai pola penerimaan Pajak Daerah dan Retribusi Daerah yang berimplikasi pada kontribusi PAD, khususnya penerimaan pajak daerah dan retribusi daerah yang diterima oleh Pemerintah Kabupaten Lamongan serta seberapa besar pengaruh kontribusi keduanya terhadap peningkatan PAD. Pendekatan yang digunakan dalam penelitian ini adalah pendekatan kualitatif dan kuantitatif dari berbagai sumber data yang diperoleh, baik data primer maupun data sekunder yang relevan. Sedangkan analisa data yang akan dianalisa dengan menggunakan data Time Series, dimana analisis ini pada hakekatnya adalah melihat pengukuran dari waktu ke waktu tertentu, yaitu cara frekuensi, persentase atau melihat kecenderungan ( control tendency ) dari suatu gejala atau kejadian.

Penelitian ini akan berusaha untuk melihat hubungan antara Pajak daerah, Retribusi Daerah terhadap peningkatan PAD. Untuk menyamakan persepsi dan memfokuskan masalah, maka perlu dijelaskan di sini bahwa data pajak daerah yang digunakan adalah data penerimaan pajak daerah yang diterima Kabupaten Lamongan, data retribusi daerah adalah penerimaan retribusi daerah yang diterima Kabupaten Lamongan, serta data PAD adalah penerimaan PAD yang diterima Kabupaten Lamongan. Seluruh data yang digunakan dalam penelitian ini mengacu pada data yang dikeluarkan oleh Pemerintah Daerah Kabupaten Lamongan. Dalam tulisan ini menggunakan data tahunan dari tahun 1990 sampai dengan tahun 2010. Data dalam tulisan ini dapat disajikan pada tabel 1 .

Selanjutnya dari data yang ada akan dilihat bagaimana hubungan antar variabel dalam bentuk regresi dengan pendekatan error correction model (ECM). Data yang digunakan dalam tulisan ini menggunakan data tahunan dengan alasan bahwa keeratan hubungan pajak daerah dan retribusi daerah dengan peningkatan PAD tidak dapat hanya dilihat dalam jangka pendek tetapi pengaruh dalam jangka panjang juga akan dilihat pengaruhnya. 
Tabel1. Pajak Daerah, Retribusi Daerah dan PAD Kabupaten Lamongan Tahun 1990-2010

\begin{tabular}{lccc}
\hline Tahun & Pajak Daerah & Retribusi Daerah & PAD \\
\hline 1990 & $1.932 .553 .225,00$ & $4.643 .745 .889,00$ & $7.956 .684 .655,89$ \\
\hline 1991 & $2.378 .996 .335,00$ & $5.147 .664 .773,00$ & $9.145 .045 .866,67$ \\
\hline 1992 & $2.453 .667 .554,00$ & $5.364 .558 .773,00$ & $9.987 .985 .457,78$ \\
\hline 1993 & $2.743 .667 .882,00$ & $5.646 .778 .334,00$ & $10.098 .779 .665,89$ \\
\hline 1994 & $2.978 .556 .443,00$ & $5.845 .633 .889,00$ & $10.254 .843 .137,87$ \\
\hline 1995 & $3.057 .886 .334,00$ & $6.058 .776 .441,00$ & $12.198 .779 .657,56$ \\
\hline 1996 & $3.267 .443 .663,00$ & $6.254 .776 .844,00$ & $12.865 .889 .136,33$ \\
\hline 1997 & $3.732 .532 .886,00$ & $6.473 .443 .667,00$ & $14.314 .478 .814,76$ \\
\hline 1998 & $4.056 .743 .667,00$ & $6.576 .337 .884,00$ & $16.442 .312 .495,24$ \\
\hline 1999 & $4.642 .554 .332,00$ & $6.897 .557 .882,00$ & $18.776 .476 .643,45$ \\
\hline 2000 & $4.957 .825 .442,00$ & $7.186 .553 .778,00$ & $19.887 .553 .198,32$ \\
\hline 2001 & $5.272 .735 .554,00$ & $7.342 .765 .554,00$ & $21.020 .208 .887,29$ \\
\hline 2002 & $5.963 .891 .664,00$ & $7.406 .789 .883,32$ & $25.453 .445 .082,39$ \\
\hline 2003 & $7.397 .214 .285,00$ & $7.631 .831 .297,00$ & $32.314 .669 .959,97$ \\
\hline 2004 & $9.180 .093 .919,00$ & $9.429 .191 .831,00$ & $34.010 .841 .136,84$ \\
\hline 2005 & $9.556 .028 .809,00$ & $12.968 .629 .823,00$ & $40.067 .207 .856,37$ \\
\hline 2006 & $10.909 .571 .668,90$ & $17.462 .829 .425,00$ & $42.441 .553 .192,83$ \\
\hline 2007 & $11.993 .879 .168,96$ & $19.618 .544 .117,00$ & $55.639 .143 .647,41$ \\
\hline 2008 & $14.271 .468 .396,00$ & $24.300 .382 .597,00$ & $66.612 .476 .978,78$ \\
\hline 2009 & $16.537 .881 .443,00$ & $24.956 .948 .945,00$ & $71.312 .587 .814,29$ \\
\hline 2010 & $14.279 .694 .165,00$ & $8.907 .897 .859,00$ & $78.162 .495 .108,25$ \\
\hline
\end{tabular}

Sumber : Instansi Keuangan Daerah Kab. Lamongan, Diolah

Dari data yang telah didapat akan diolah dengan metode ECM. Langkah pertama yang perlu dilakukan yaitu dengan menampilkan stasioneritas data. Uji stasioneritas data menggunakan uji unit root square yang dikembangkan oleh Dickey - Fuller, atau dikenal juga dengan nama uji ADF. Langkah yang dilakukan adalah dengan membandingkan nilai $\mathrm{t}$ statistic dengan nilai critical value-nya. Jika nilai $\mathrm{t}$ - statistic lebih besar dari nilai critical value, maka suatu variabel dikatakan stasioner. Dari olah data menggunakan e-views, didapat hasil stasioner yang disajikan dalam tabel 2 .

Tabel 2. Hasil Olah Data

\begin{tabular}{|l|l|l|}
\hline \multicolumn{1}{|c|}{ Variabel } & \multicolumn{1}{c|}{ ADF Test Statistic } & MacKinnon critical \\
\hline PD & -3.724 & $-3.69^{*}$ \\
\hline RD & -5.34 & $-3.03^{*}$ \\
\hline PAD & -3.58 & $-3.29^{* *}$ \\
\hline$* 5 \%$ &
\end{tabular}

$* * 10 \%$

Untuk uji stasioneritas data dapat disimpulkan di sini, bahwa dari tiga variabel yang diamati, variabel pajak daerah telah stasioner pada $\mathrm{I}=(1)$, variabel retribusi daerah telah stasioner pada $\mathrm{I}=(0)$ dan variabel PAD telah stasioner pada $\mathrm{I}=(1)$. 
Langkah kedua yaitu karena PD (pajak daerah) dan PAD (Pendapatan Asli Daerah) berada pada I (1) maka perlu diperlukan uji kointegrasi kedua variabel.

Dengan membandingkan nilai ADF stat dari nilai sisa ( resid) PD dan PAD dengan MacKinnon maka diperoleh hasil -2.41 dengan MacKinnon value -1.96 pada 5\%. maka bisa dikatakan bahwa variabel - variabel tersebut berkointegrasi. Apabila variabel - variabel ternyata saling berkointegrasi, berarti ada hubungan jangka panjang (atau keseimbangan) antara variabel - variabel yang diteliti. Dalam jangka pendek ada kemungkinan terjadi ketidak seimbangan. Karena adanya ketidakseimbangan ini, maka diperlukan adanya ECM.

Langkah selanjutnya adalah dengan membentuk model ECM. Model umum ECM adalah $\mathrm{DY}_{\mathrm{t}}=\beta_{0}+\beta_{1} \mathrm{DX}_{\mathrm{t}-1}+$ $\beta_{2} X_{t}+\beta_{3} E C T$ dimana: $Y=$ Variabel terikat (dependent variable) $\mathrm{X}=$ Variabel bebas (independent variable) $\mathrm{DY}_{\mathrm{t}}=\mathrm{Y}_{\mathrm{t}}-$ $\mathrm{Y}_{\mathrm{t}-1,}, \quad \mathrm{DX}_{\mathrm{t}}=\mathrm{X}_{\mathrm{t}}-\mathrm{X}_{\mathrm{t}-1} \quad E C T=\mathrm{X}_{\mathrm{t}-1}-\mathrm{Y}_{\mathrm{t}-1}$. ECM mempunyai ciri khas dengan dimasukkannya unsur Error Correction Term (ECT) dalam model. Apabila koefisien $E C T$ signifikan secara statistik dan mempunyai tanda positif, maka spesifikasi model yang digunakan dalam penelitian tersebut adalah valid dan bisa dilanjutkan untuk penelitian selanjutnya.

Selanjutnya, model koreksi kesalahan $(E C M)$ dapat diturunkan dari fungsi biaya kuadrat tunggal (single period quadratic cost function). Mengikuti pendekatan yang dikembangkan oleh Domowitz dan Elbadawi (1987) dengan terlebih dahulu melakukan minimisasi terhadap fungsi biaya kuadrat tunggal, akan diperoleh bentuk baku model koreksi kesalahan $(E C M)$ yang akan digunakan sebagai model estimasi dalam penelitian ini

$\operatorname{DPAD}_{\mathrm{t}}=\beta_{0}+\beta_{1} \mathrm{DPD}_{\mathrm{t}-1}+\beta_{2} \mathrm{DRD}_{\mathrm{t}}+\beta_{3}$ $\mathrm{DPAD}_{\mathrm{t}-1}+\beta_{4} \mathrm{ECT}$

Dimana;

$\mathrm{DPAD}_{\mathrm{t}}=\mathrm{PAD}_{\mathrm{t}}-\mathrm{PAD}_{\mathrm{t}-1 .} . \mathrm{DPD}_{\mathrm{t}}=\mathrm{PD}_{\mathrm{t}}-$ $\mathrm{PD}_{\mathrm{t}-1} \quad \mathrm{DRD}_{\mathrm{t}}=\mathrm{RD}_{\mathrm{t}}-\mathrm{RD}_{\mathrm{t}-1} \quad \mathrm{ECT}=$ $\mathrm{PD}_{\mathrm{t}-1}+\mathrm{RD}_{\mathrm{t}-1}-\mathrm{PAD}_{\mathrm{t}-1}, \mathrm{ECT}>0$ dan $0<\beta_{3}$ $<1$

Dari hasil estimasi di atas, dapat dijelaskan di sini bahwa model yang coba dibangun dengan dengan ECM, dikatakan berhasil. Ini bisa diketahui dari hasil koefisien variable ECT yang signifikan secara statistik dan bertanda positif. Dari hasil uji $\mathrm{F}$ dapat disampaikan di sini bahwa secara bersama - sama variabel independen (pajak daerah dan retribusi daerah) mempunyai pengaruh kepada variabel dependen (pendapatan asli daerah). Dari uji $\mathrm{T}$ didapat hasil bahwa variabel pajak daerah dan variabel retribusi daerah keduanya secara individual berpengaruh secara signifikan terhadap variabel Pendapatan Asli Daerah. Nilai $\mathrm{R}^{2}$ dari regresi di atas menunjukkan angka $1 \%$ yang berarti bahwa $100 \%$ dari variasi PAD dapat dijelaskan oleh variasi himpunan variabel bebasnya. Sedangkan sisanya (berkisar 0\%) dipengaruhi oleh 


\begin{tabular}{|c|c|c|c|c|}
\hline \multicolumn{5}{|c|}{$\begin{array}{l}\text { Tabel 3. Hasil Olah Data } \\
\text { Dependent Variable: D(PAD) } \\
\text { Method: Least Squares } \\
\text { Date: 12/15/10 Time: } 12: 41 \\
\text { Sample(adjusted): } 19912010 \\
\text { Included observations: } 20 \text { after adjusting endpoints }\end{array}$} \\
\hline Variable & Coefficient & Std. Error & $\mathrm{t}$-Statistic & Prob. \\
\hline $\mathrm{C}$ & -3.310742 & $2.49 \mathrm{E}-13$ & $-1.33 E+13$ & 0.0000 \\
\hline $\mathrm{D}(\mathrm{PD})$ & 4.793133 & $3.02 \mathrm{E}-13$ & $1.59 \mathrm{E}+13$ & 0.0000 \\
\hline $\mathrm{D}(\mathrm{RD})$ & $1.69 \mathrm{E}-13$ & $6.84 \mathrm{E}-14$ & 2.474620 & 0.0279 \\
\hline $\mathrm{PD}(-1)$ & 4.793133 & $2.69 \mathrm{E}-13$ & $1.78 \mathrm{E}+13$ & 0.0000 \\
\hline $\mathrm{RD}(-1)$ & $-1.29 \mathrm{E}-13$ & $6.63 \mathrm{E}-14$ & -1.945446 & 0.0737 \\
\hline $\mathrm{PAD}(-1)$ & -1.000000 & $7.25 \mathrm{E}-14$ & $-1.38 \mathrm{E}+13$ & 0.0000 \\
\hline ECT & 1.000000 & $4.55 \mathrm{E}-14$ & $2.20 \mathrm{E}+13$ & 0.0000 \\
\hline R-squared & 1.000000 & \multirow{5}{*}{\multicolumn{2}{|c|}{$\begin{array}{l}\text { Mean dependent var } \\
\text { S.D. dependent var } \\
\text { Sum squared resid } \\
\text { Durbin-Watson stat }\end{array}$}} & 3.510300 \\
\hline Adjusted R-squared & 1.000000 & & & 3.627842 \\
\hline S.E. of regression & $3.75 \mathrm{E}-13$ & & & $1.83 \mathrm{E}-24$ \\
\hline F-statistic & $2.97 \mathrm{E}+26$ & & & 2.826697 \\
\hline Prob(F-statistic) & 0.000000 & & & \\
\hline
\end{tabular}

$$
\mathrm{DPAD}_{\mathrm{t}}=-3.31+4.79 \mathrm{DPD}_{\mathrm{t}}+1.69 \mathrm{DRD}_{\mathrm{t}}+4.79_{\mathrm{t}-1}-1.29_{\mathrm{t}-1}+1.00 E C T
$$

\section{PEMBAHASAN}

Dari variabel pajak daerah, variabel ini mempunyai pengaruh yang positif terhadap PAD, kenyataan ini sesuai dengan teori bahwa pajak daerah merupakan salah satu komponen yang dapat menaikkan PAD/memberikan kontribusi pada PAD, dimana apabila terjadi kanaikan pajak daerah, maka akan menaikkan nilai PAD juga. Selanjutnya variabel pajak daerah merupakan suatu instrumen yang dipakai oleh pemerintah daerah untuk dapat meningkatkan pendapatan asli daerah.

$$
\text { variabel retribusi daerah }
$$

mempunyai pengaruh yang positif terhadap PAD, kenyataan ini sesuai dengan teori bahwa retribusi daerah merupakan salah satu komponen yang dapat menaikkan PAD/membrikan kontribusi terhadap PAD, dimana apabila terjadi kanaikan retribusi daerah, maka akan menaikkan nilai PAD juga. Selanjutnya variabel retribusi daerah merupakan suatu instrumen yang dipakai oleh pemerintah daerah untuk dapat meningkatkan pendapatan asli daerah.

Secara teoritis, PAD dipengaruhi oleh pajak daerah dan retribusi daerah disamping pendapatan daerah lain yang sah, karena kedua pendapatan tersebut, yaitu pajak daerah dan retribusi daerah secara langsung maupun tidak langsung membebani masyarakat. Meningkatnya PAD secara langsung akan berpengaruh juga terhadap PDRB dan APBD.Data dan hasil regresi dengan menggunakan model ECM di atas dengan jelas menggambarkan hubungan tersebut. Baik variabel pajak daerah maupun retribusi daerah sama sama menunjukkan bahwa kedua variabel 
tersebut

mempengaruhi

PAD di

Kabupaten

Lamongan.

\section{DAFTAR PUSTAKA}

Agus Widarjono,1995, Ekonometrika Teori dan Aplikasinya Untuk Ekonomi dan Bisnis, Ekonisia Kampus Fakultas Ekonomi UII, Yogyakarta

Abdul Halim,2001, Bunga Rampai Manajemen Keuangan Daerah, Edisi Revisi, Penerbit dan Percetakan (UUP) AMP YPKN, Yogyakarta.

Davey, K.J, 1988, Pembiayaan Pemerintah Daerah, praktek-praktek

Internasional dan

Relevansinya Bagi Dunia

Ketiga, penerbit UI Press,Edisi Jakarta.

Wing Wahyu Winarno, 2007, Analisis Ekonometrika dan Statistik Dengan E-Views, Unit Penerbit dan Percetakan Sekolah Tinggi Ilmu manajemen YKPN, Jogjakarta

Arbi Sanit, 1999, Format Otonomi Daerah Masa Depan, Sekolah Tinggi Pembangunan Masyarakat Desa "APMD"

Undang-undang RI Nomor 32 Tahun 2004, Tentang Pemerintahan Daerah.

Undang-undang RI Nomor 33 Tahun 2004, Tentang Perimbangan Keuangan antara Pemerintah Pusat dan Daerah.

Yosef Riwo Kaho, 2001, Prospek Otonomi Daerah di Negara Kesatuan Republik Indonesia, PT. Raja Grafindo Persada, Jakarta

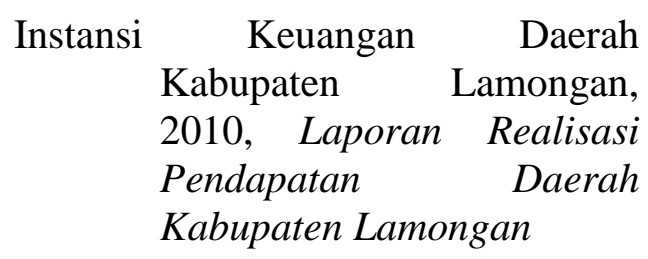

Makara Sosial Humaniora, 2003, Vol. 7 No. 2 Desember 2003. 